\title{
Detection of nephritis strain-associated streptokinase by monoclonal antibodies
}

\author{
H. OHKUNI, YUKO TODOME, K. YOSHIMURA*, T. YAMAMOTO*, H. SUZUKI, \\ K. YOKOMURO*, K. H. JOHNSTON $†$ and J. B. ZABRISKIE‡
}

Division of Immunology, Institute of Gerontology, Nippon Medical School, 1-396, Kosugi-cho, Nakahara-ku, Kawasaki, Kanagawa 211, Japan, 'Department of Microbiology and Immunology, Nippon Medical School, Tokyo, Japan, tDepartment of Microbiology, Immunology and Parasitology, Louisiana State University Medical Center, New Orleans, LA and $\ddagger$ Laboratory of Bacteriology and Immunology, The Rockefeller University, New York, USA

\begin{abstract}
Summary. Monoclonal antibodies (MAbs) N-59 and RU-1 were produced by immunisation of mice with streptokinase secreted by Streptococcus group A, type 12, strain A374 isolated from a patient with post-streptococcal glomerulonephritis (PSGN) and were characterised by Western blot analysis. MAb N-59 recognised antigenic determinants shared by both nephritis strain-associated streptokinase (NSA-SKase) and streptokinase of Streptococcus group C (C-SKase); MAb RU-1 reacted only with NSA-SKase. All nephritis-associated group A streptococcal strains tested reacted with MAb N-59;87.5\% of these strains reacted with MAb RU-1. MAb N-59 reacted with SKase produced by group G streptococcal strains isolated from patients with PSGN, and MAb RU-1 recognised SKase in two out of three of these strains.
\end{abstract}

\section{Introduction}

It has been reported that group A streptococci isolated from patients with post-streptococcal glomerulonephritis (PSGN) produce an extracellular protein that has a subunit of $46 \mathrm{Kda}$, as determined by sodium dodecyl sulphate-polyacrylamide gel electrophoresis (SDS-PAGE). This protein (not secreted generally by streptococcal strains isolated from patients without PSGN) was called the nephritis strain-associated protein (NSAP). ${ }^{1}$ Subsequently, the amino-acid composition and the first $21 \mathrm{~N}$-terminal amino-acid sequence analysis of NSAP demonstrated that this molecule was streptokinase, but antigenically it proved to be different from the streptokinase of group $\mathrm{C}$ streptococci. $^{2}$

In this paper, NSAP is designated nephritis strainassociated SKase (NSA-SKase) and its presence was investigated in the supernates of cultures of group $A$, $B, C$ and $G$ streptococci, isolated from patients with or without PSGN, by Western blot analysis with monoclonal antibodies (MAbs) prepared against NSA-SKase.

\section{Materials and methods}

\section{Bacterial strains}

Clinical isolates of group A, B, C and G streptococci were investigated; some group A streptococci were obtained from the Rockefeller University collection.
Strain A 374, a streptococcus of group A, type M12, was used as the standard strain for NSA-SKase isolation. ${ }^{3}$ All of these strains were pharyngeal isolates from patients.

\section{Extraction of extracellular products}

Bacterial strains were grown in a chemically defined medium ${ }^{4}$ at $37^{\circ} \mathrm{C}$ and 10 -ml samples were removed at different times during growth $(4,6,8,10,12,18$ and $24 \mathrm{~h}$ ). Cells were removed by centrifugation, and the proteins in the supernate were precipitated by the addition of cold trichloroacetic acid (TCA) as described previously. ${ }^{2}$ After centrifugation, TCA-precipitated pellets were washed with cold ethanol $95 \%$ containing $2 \mathrm{M}$ sodium acetate $5 \% \mathrm{v} / \mathrm{v}$. The pellets were suspended in distilled water and the proteins were separated by SDS-PAGE. ${ }^{5}$ NSA-SKase, which has a $M_{r}$ of $46 \mathrm{Kda}$, appeared after growth for 6-8 h and then appeared to break down after $8 \mathrm{~h}$ (data not shown). Therefore, in the present studies, cultures were grown for $8 \mathrm{~h}$ only.

\section{Purification of NSA-SKase}

Purification of NSA-SKase was by the method of Johnston and Zabriskie. ${ }^{2}$ The fraction containing NSA-SKase was eluted from a DEAE-Sepharose CL6B (Sigma) ion exchange column, then applied to a Sephadex G-100 (Pharmacia Fine Chemicals, Uppsala, Sweden) column and eluted with $0.1 \mathrm{M}$ phosphate buffer ( $\mathrm{pH} 7.5)$ containing $0.2 \mathrm{M} \mathrm{NaCl}$. This fraction was dialysed against $25 \mathrm{~mm}$ piperazine (Sigma),

Received 4 Oct. 1990; accepted 26 Nov. 1990. 
$\mathrm{pH} 6.0$, and was applied to a chromatofocusing (PBE 94; Pharmacia) column. The column was developed with polybuffer 74 (Pharmacia), diluted 1 in 10 and titrated to $\mathrm{pH} 4 \cdot 0$. NSA-SKase was identified by SDS-PAGE, ${ }^{3,5}$ immunodot $^{2}$ and Western blot ${ }^{2,6}$ analyses with MAb prepared against NSA-SKase.

\section{Production of MAb to NSA-SKase}

BALB/c mice were given an initial intraperitoneal (i.p.) injection of $250 \mu \mathrm{g}$ of extracellular products (ECP) of strain A374 emulsified in Freund's incomplete adjuvant (FICA) (Difco). They were then given 250- $\mu \mathrm{g}$ of ECP with FICA by i.p. injection each week for 4 weeks. After the last injection, they were given an intravenous injection of $500 \mu \mathrm{g}$ of ECP alone. Three days later, spleen cells were removed and spleen cell-myeloma cell (NS-1) hybrids were prepared. The supernates of hybridoma cells were assayed by enzymelinked immunosorbent assay with an electrophoretically purified NSA-SKase preparation ${ }^{3}$ and the MAb immunoglobulin (Ig) subclasses were determined by double immunodiffusion techniques with commercially prepared subclass-specific antisera (Serotec Ltd, Bicester). One hybridoma used in this study was designated $\mathrm{N}-59$; the other, designated RU-1, was prepared as described previously. ${ }^{2}$ Both MAbs were of $\mathrm{IgG}_{1}$ subclass.

\section{Iso-electric focusing}

Purified NSA-SKase was iso-electric focused in a thin layer of Sephadex IEF gel at $30 \mathrm{~W}$ for $6 \mathrm{~h}$, with $\mathrm{pH}$ range $3 \cdot 0-10$, in the flat bed apparatus FBE 3000 according to the Pharmacia Instruction Manual. The sample $(15 \mu \mathrm{l})$ was loaded on to the gel with an applicator and a broad pI callibration kit was used as standard markers.

\section{SKase activity}

SKase activity was assayed by fibrin clot resolving activity. ${ }^{7}$ SKase and reference SKase (Lederle Laboratories, Pearl River, NY, USA) were added to human euglobulin solution (as plasminogen source). Bovine fibrinogen (Miles Scientific, Naperville, IL, USA) and thrombin (Mochida Pharmaceutical Co., Tokyo, Japan) were added to the above mixture, and clots were incubated for $10 \mathrm{~min}$ in a water-bath at $37^{\circ} \mathrm{C}$. A unit of SKase activity was defined as the amount of SKase that lysed the fibrin clot in $10 \mathrm{~min}$.

\section{Results and discussion}

Fig. 1 illustrates the purification of NSA-SKase from strain A374. NSA-SKase from the chromato-

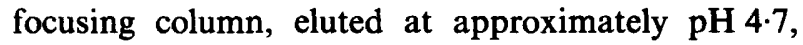
showed only a single band corresponding to $46 \mathrm{Kda}$ on SDS-PAGE (lane D). The pI of NSA-SKase was

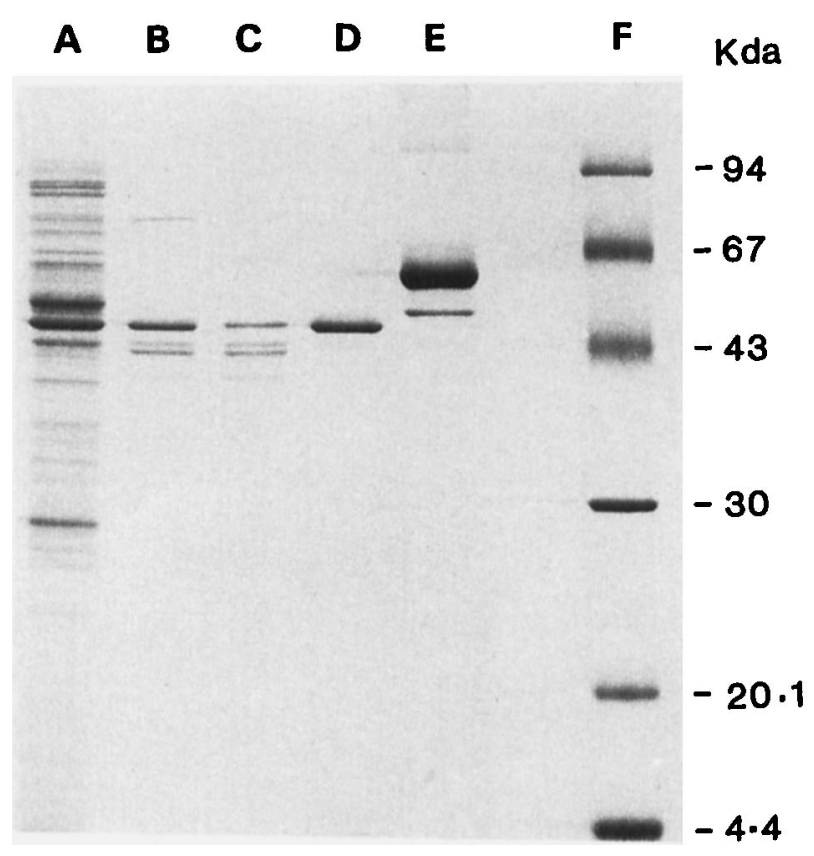

Fig. 1. SDS-PAGE profile of NSA-SKase ( $46 \mathrm{Kda}$ ) extracted from Streptococcus group A, type 12, strain A374. Lane A, crude extracellular products; B, fraction eluted from DEAE-Sepharose CL-6B column; C, fraction eluted from Sephadex G-100 column; D, fraction eluted from chromatofocusing column; E, streptokinase of Streptococcus group C; F, mol.-wt marker.

4.78. Lane E shows group C streptokinase (C-SKase) (Sigma) isolated from strain H46A, Streptococcus equisimilis. The heavy band in lane $\mathrm{E}$ is human serum albumin used as a stabiliser. NSA-SKase from the chromatofocusing column had SKase activity (26 $243 \mathrm{U} / \mathrm{mg}$ ) and its activity was 230 -fold greater than the SKase activity of the original ECP of strain A374.

In Western blot analysis with two MAbs ( -59 and RU-1) as immunological probes, MAb N-59 reacted with both NSA-SKase from strain A374 and C-SKase (fig. 2, lanes 3 and 4), but MAb RU-1 reacted only with NSA-SKase (fig. 2, lanes 1 and 2). These results suggest that NSA-SKase has at least two antigenic domains. MAb N-59 recognised the same epitope, which is shared by both NSA-SKase and C-SKase, whereas the NSA-SKase-specific epitope reacted with MAb RU-1. Therefore, NSA-SKase possesses antigenic domains different from those present in CSKase. Johnston and Zabriskie ${ }^{2}$ reported that there were antigenic differences between NSA-SKase and C-SKase, and the presence of different epitopes in NSA-SKase and C-SKase was further confirmed by the use of MAbs.

Strains of group A(75), group B(4), group C(6) and group $G$ (11) streptococci were analysed for the presence of NSA-SKase in TCA-precipitated pellets with MAbs N-59 and RU-1 in Western blot analysis (table I). These strains were selected at random from clinical laboratory isolates. However, it was not clear whether these strains had been isolated from patients with PSGN. Out of the 96 strains of groups A, B, C and G streptococci, $68(70.8 \%)$ reacted with MAb N59 . However, only $26(27.1 \%)$ strains reacted with 


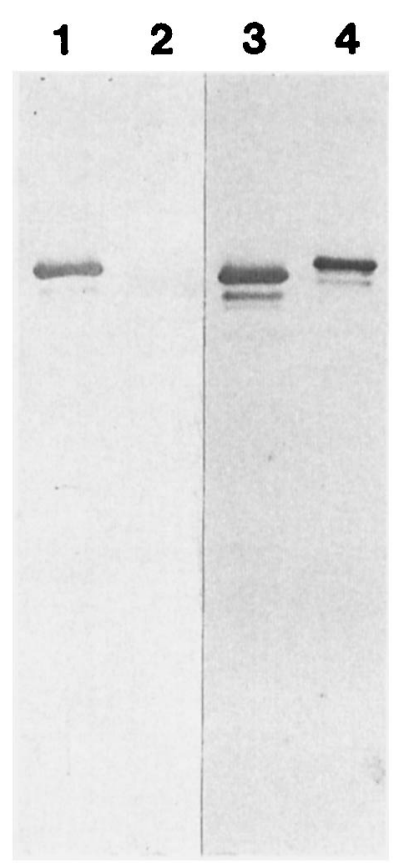

Fig. 2. Western blot analysis of purified NSA-SKase and group CSKase: lanes 1 and 3, NSA-SKase; 2 and 4, C-SKase. After SDSPAGE, protein bands were transferred to nitrocellulose membrane; the MAbs used were: MAb RU-1, lanes 1 and 2; MAb N-59, lanes 3 and 4.

Table I. Presence of NSA-SKase in culture supernates of streptococcal strains detected by Western blot analysis with two MAbs

\begin{tabular}{cc|cc}
\hline & & \multicolumn{2}{|c}{$\begin{array}{c}\text { Number of strains that reacted/number } \\
\text { tested with MAb }\end{array}$} \\
\cline { 3 - 4 } $\begin{array}{c}\text { Streptococcal } \\
\text { group }\end{array}$ & T-type & N-59 & RU-1 \\
\cline { 3 - 4 } & & $2 / 11$ & $1 / 11$ \\
& 1 & $0 / 1$ & $0 / 1$ \\
& 3 & $16 / 22$ & $8 / 22$ \\
& 4 & $2 / 3$ & $1 / 3$ \\
& 6 & $3 / 3$ & $1 / 3$ \\
& 8 & $11 / 15$ & $9 / 15$ \\
& 12 & $5 / 7$ & $0 / 7$ \\
& 13 & $1 / 1$ & $0 / 1$ \\
& 14 & $8 / 8$ & $2 / 8$ \\
& 22 & $3 / 4$ & $2 / 4$ \\
(Total) & 28 & $(51 / 75)$ & $(24 / 75)$ \\
& & $(68 \%)$ & $(32 \%)$ \\
B & & $0 / 4$ & $0 / 4$ \\
C & & $6 / 6$ & $0 / 6$ \\
G & & $11 / 11$ & $2 / 11$ \\
& & $68 / 96$ & $26 / 96$ \\
Total & & $(70 \cdot 8 \%)$ & $(27 \cdot 1 \%)$ \\
& & & \\
\hline
\end{tabular}

UT, untypable strain.

both MAbs N-59 and RU-1. Two out of 11 group G streptococcal strains also reacted with both MAbs.

In the experiments to detect the presence of NSASKase in streptococcal strains isolated from welldocumented cases of PSGN, all of 16 group A streptococcal strains reacted with MAb N-59 (table II). MAb RU-1 reacted with only $14(87.5 \%)$ of
Table II. Presence of NSA-SKase in culture supernates of streptococcal strains isolated from the pharynges of patients with PSGN detected by Western blot analysis with two MAbs

\begin{tabular}{|c|c|c|c|c|}
\hline \multirow{2}{*}{$\begin{array}{l}\text { Streptococcal } \\
\text { groups }\end{array}$} & \multicolumn{2}{|c|}{ Types } & \multicolumn{2}{|c|}{$\begin{array}{l}\text { Number of strains that } \\
\text { reacted/number tested } \\
\text { with MAb }\end{array}$} \\
\hline & $T$ & $\mathbf{M}$ & N-59 & RU-1 \\
\hline A & $\begin{array}{r}4 \\
6 \\
8 \\
12 \\
\ldots \\
\ldots \\
\ldots \\
\ldots\end{array}$ & $\begin{array}{r}\ldots \\
\ldots \\
\ldots \\
\ldots \\
4 \\
12 \\
49 \\
57\end{array}$ & $\begin{array}{l}5 / 5 \\
1 / 1 \\
1 / 1 \\
3 / 3 \\
1 / 1 \\
3 / 3 \\
1 / 1 \\
1 / 1\end{array}$ & $\begin{array}{l}4 / 5 \\
1 / 1 \\
1 / 1 \\
3 / 3 \\
0 / 1 \\
3 / 3 \\
1 / 1 \\
1 / 1\end{array}$ \\
\hline (Total) & & & $\begin{array}{l}(16 / 16) \\
(100 \%)\end{array}$ & $\begin{array}{l}(14 / 16) \\
(87.5 \%)\end{array}$ \\
\hline G & & & $3 / 3$ & $2 / 3$ \\
\hline Total & & & $\begin{array}{l}(19 / 19) \\
(100 \%)\end{array}$ & $\begin{array}{l}(16 / 19) \\
(84 \cdot 2 \%)\end{array}$ \\
\hline
\end{tabular}

the 16 strains. When three group $G$ streptococcal strains were analysed, MAb N-59 reacted with all strains, and MAb RU-1 recognised two (67\%) of the three strains. Western blot analysis of isolates from patients with and without PSGN are shown in fig. 3. After SDS-PAGE, the NSA-SKase contained in TCAprecipitated pellets was detected by both MAbs N-59 and RU-1. Lanes A-D and F-I show the TCAprecipitated pellets from strains isolated from patients without and with PSGN, respectively. Lane E contained NSA-SKase purified from strain A374 (fig. 3, I). MAb RU-1 reacted only with NSA-SKase from strains isolated from patients with PSGN.

Although strains non-reactive with MAb N-59 were cultured for $2-24 \mathrm{~h}$ at $37^{\circ} \mathrm{C}$, they failed to secrete SKase which would react with MAb N-59 in culture supernates. It is unclear why three strains (two of group A and one of group G) isolated from the pharynges of patients with PSGN were unable to secrete NSA-SKase in culture supernates that would react with MAb RU-1. However, 87.5\% (14 out of 16) of strains of group A and $67 \%$ ( 2 out of 3 ) of strains of group $G$ streptococci isolated from patients with PSGN secreted NSA-SKase in culture supernates. Thus, the production of NSA-SKase is associated closely with the development of PSNG and it is interesting that NSA-SKase is produced from group G streptococcal strains isolated from patients with PSGN.

In group A, streptococcal strains isolated from patients with PSGN strains of types 4 and 12 secreted NSA-SKase at high frequency. However, strains of other types also secreted NSA-SKase. Therefore, the production of NSA-SKase by streptococci appears to be strain- rather than type-specific (tables I and II). 
A A B C D E F G H I

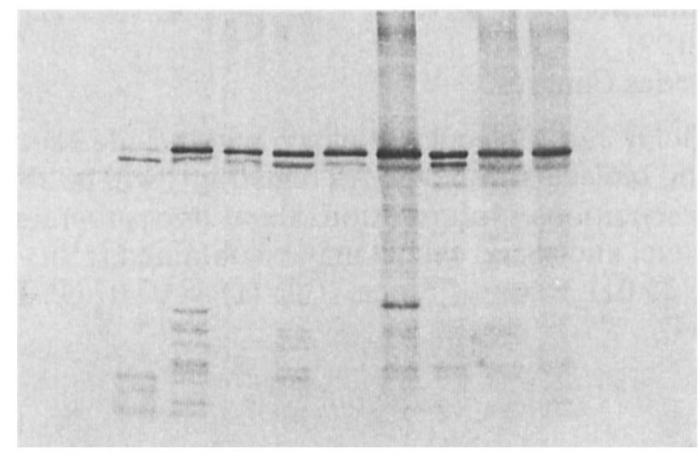

B A B C D E F G H I

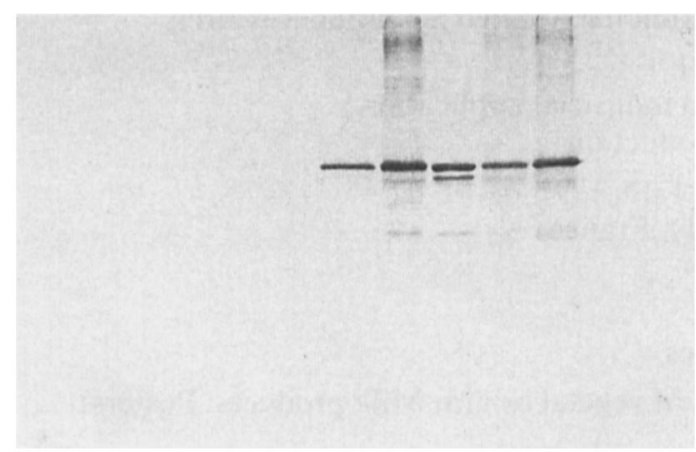

As NSA-SKase was easily identified in culture supernates of streptococcal strains by Western blot analysis with MAb to NSA-SKase, this method may be a useful tool in epidemiological surveys. Furthermore, strains which could potentially cause nephritis could be identified early, and allow preventive measures to be instituted.

We are grateful to Dr T. Poon-King, Department of Medicine, San Fernando General Hospital, San Fernando; Dr T. Yamada, Department of Microbiology, Medical College of Yamanashi, Yamanashi; Dr S. Murai, Department of Public Health, Toho University, School of Medicine, Tokyo and Dr E. Tamahana, Department of Pediatrics, Nakagame Hospital, Naha, Okinawa, for providing the streptococcal strains used in this study.

Fig. 3. Western blot analysis of culture supernates from strains of group A streptococci isolated from patients with or without PSGN : lanes A-D, strains from patients without PSGN; F-I strains from patients with PSGN; E, purified NSA-SKase. Proteins precipitated with TCA $10 \%$ were separated by SDS-PAGE and transferred to nitrocellulose membrane, and NSA-SKase was detected with (a) MAb N-59 and (b). MAb RU-1.

4. van de Rijn I, Kessler RE. Growth characteristics of group A streptococci in a new chemically defined medium. Infect Immun 1980; 27: 444-448.

5. Laemmli UK. Cleavage of structural proteins during the assembly of the head of bacteriophage T4. Nature 1970; 227: $680-685$.

6. Towbin H, Staehelin T, Gordon J. Electrophoretic transfer of proteins from polyacrylamide gels to nitrocellulose sheets: procedure and some application. Proc Natl Acad Sci USA $1979 ; 76: 4350-4354$.

7. Dillon HC, Wannamaker LW. Physical and immunological differences among streptokinases. J Exp Med 1965; 121: 351-371. 